\title{
Exploring Factors Affecting the Effectiveness of Business Training in the Microfinance Sector: Using the Industrial Marketing Purchasing (IMP) Approach
}

http://doi.org/10.21272/bel.4(3).46-56.2020

Ruwan Abeysekera, ORCID: https://orcid.org/0000-0002-2858-6483

$\mathrm{PhD}$, Senior Lecturer, Department of Finance, Faculty of Commerce and Management Studies, University of Kelaniya, Kelaniya, Sri Lanka

\begin{abstract}
Microfinance institutions provide business training to its clients/owner managers to start and expand businesses. The literature reveals that business training given by MFIs helps improve the performance of both the MFIs and its clients (i.e., Owner managers of microenterprises). In effect, due to business training, MFIs can have improved loan repayment rates, client retention, and client satisfaction, while the owner-managers can have better sales, profits, and skills. However, despite the importance of business training to both MFIs and owner-managers' performance, there is a dearth of research undertaken to explore the effectiveness of business training intervention in microfinance setting. In this study, effectiveness is defined in terms of the impact of business training on the performance of MFIs and owner-managers (i.e., training - performance dyad). Hence, the purpose of this exploratory study is to examine the factors affecting the effectiveness of business training given by the MFIs in Sri Lanka. A multiple case study method was used to carry out the study. The study was guided by the Industrial Marketing Purchasing (IMP) group framework. Thus, the study looks at how operating environment, atmosphere, interacting parties and the interaction process affect the effectiveness of the training intervention. The findings reveal that lack of money and low client demand for the operating environment influence training effectiveness. Further, it was identified that factors such as better loan repayment and new venture creation motivate the MFIs to provide business training, whereas better business knowledge and business performance motivate the owner-managers to receive business training. These motivators are part of the atmosphere that has a bearing on the effectiveness of business training. The findings further show that the characteristics of the interacting parties (i.e., trainers and trainees in this study) could affect business training effectiveness. Thus, the trainer's expertise, trainer being internal or external, and trainer being full time or part-time can influence the training-performance dyad. Further, the owner-managers' expertise and organizational structure could also affect the effectiveness of training. Several factors enhance the interaction between trainers and owner-managers. They are the trainer's expertise and the ownermanager/client, trainer readiness, communication, follow-up procedures, feedback, and owner manager's willingness. Further, location, duration of the training, charging a fee or not, the voluntary/compulsory nature of training, and the provision of subsidies also could enhance the interaction between the trainers and the owner-managers. Therein, this study contributes to the knowledge domain of microfinance. The findings are useful to practitioners and policymakers in microfinance as they can look at the IMP framework to identify factors that could enhance the business training-performance dyad. In this study, the client and the ownermanager are used interchangeably.
\end{abstract}

Keywords: Microfinance, Business Training, Business Development Services, Case Study Method, IMP Framework.

JEL Classification: M10.

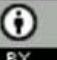

This work is licensed under a Creative Commons Attribution 4.0 International License

Cite as: Abeysekera, R. (2020). Exploring Factors Affecting the Effectiveness of Business Training in The Microfinance Sector: Using Industrial Marketing Purchasing (IMP) Approach. Business Ethics and Leadership, 4(3), 46-56. http://doi.org/10.21272/bel.4(3).46-56.2020.

(C) The Author, 2020. This article is published with open access at Sumy State University.

\section{Introduction}

In addition to the provision of microcredit, Microfinance Institutions (MFIs) provide business training to its clients under the heading of business development services (BDS) (Khavul, 2010; ADB, 1997). Under the 
umbrella of business training, MFIs provide training such as record keeping, business plan preparation, idea generation, marketing, costing, inventory management, and business planning. MFIs further provide communication and leadership training under business training (Sievers and Vandenberg, 2007; Henry, 2006). The literature on the subject (Sievers and Vandenberg, 2007; Karlan and Valdivia, 2006; De Wildt, 2004; Halder, 2003) shows that business training improves the performance of MFIs and clients/owner-managers. MFIs could have better loan repayment rates, increased client retention and client loyalty due to the provided business training. Owner managers could improve their business performance through enhanced business knowledge and skills gained through the business training and could have better profits and sales (Sievers and Vandenberg, 2007; Karlan and Valdivia, 2006; De Wildt, 2004; Halder, 2003). Due to these benefits, MFIs must provide effective business training programs to its clients to improve both parties' performance. Extant literature on microfinance (Copestake et al., 2001; Henry, 2006; Karlan and Valdivia, 2006) delineating the relationship between business training and business performance has considered only a few variables such as training program and performance and thus, have overlooked many variables such as external context, the characteristics of trainers and trainees, duration, as well as the timing and location of the training intervention. All these variables have a profound impact on the training-performance dyad. It is very difficult to identify these variables using a quantitative methodology in research (Patton et al., 2000).

Further, the literature on microfinance (Copestake et al., 2001; Henry, 2006; Karlan and Valdivia, 2006) has not considered the complexity of identifying the variables/factors that have a bearing on a training-performance dyad. Thus, a qualitative approach is suitable for identifying variables and addressing the complexity arising in the business training-performance dyad. Further, this study uses the Industrial Marketing Purchasing (IMP) group framework as the theoretical underpinning to identify factors that influence the business training intervention leading to performance. Thanks to this framework, this paper argues that the operating environment, atmosphere, interacting parties, and the interaction process influence the training-performance dyad. Thus, the questions of this study are: How does the operating environment affect business trainingperformance dyad? How does the atmosphere affect the business training-performance dyad? How do interacting parties affect the business training-performance dyad? How does the interaction process affect business training-performance dyad? An exploratory case study method (i.e., qualitative approach) is used in this study, which facilitates the identification of factors/variables that influence the training-performance dyad. The remainder of the article is organized as follows. Firstly, the literature review is presented. The next section explains the research methodology and then thirdly, the findings are presented. Finally, the discussion, conclusions and implications are offered.

\section{Literature Review}

2.1 Microfinance in Sri Lanka. Sri Lanka has a well-established microfinance sector consisting of more than 100 years old history (GTZProMis, 2010; Tilakaratne et al., 2005). There are government-owned MFIs, cooperative banks/societies, non-bank financial institutions, non-governmental organizations (NGOs) and bank MFIs that operate in Sri Lanka, covering the whole island (GTZProMis, 2010). These MFIs provide services to clients such as microcredit, counseling, business training, vocational training, savings, and insurance. The Sri Lankan government plays an active role in promoting microfinance in Sri Lanka, given its importance in poverty alleviation through livelihood development (NEDA, 2013; GTZProMis, 2010; Tilakaratne et al., 2009). Many Sri Lankan MFIs provide business training to their clients under the heading of business development services (BDS). BDS are non-financial services provided by MFIs, including business training, vocational training skills, technology access, and marketing assistance (Khavul, 2010; Henry, 2006; Sievers and Vandenberg, 2007). This study focuses only on the provision of business training under BDS.

2.2 Business Training. MFIs provide different training types such as business training, financial literacy training, and vocational training to its clients (Henry, 2006). However, this study focuses only on business training. In this context, MFIs provide business training in idea generation, business plan preparation, record keeping, marketing, costing, and business planning. MFIs use their trainers (i.e., internal) or external trainers to provide business training (Abeysekera, 2016). Studies conducted on microfinance (Copestake et al., 2001; Henry, 2006; Karlan and Valdivia, 2006) indicate that the business training provided by MFIs is beneficial to both MFIs and its clients. Business training improves loan repayments and client outreach, reduces client dropouts, and improves employee motivation and is useful to MFIs. Furthermore, business training improves sales and profits of owner-managers of microenterprises and enhances their business knowledge and practice (Karlan and Valdivia, 2006; De Wildt, 2004; ADEMCOL, 2001).

2.3 Factors affecting the effectiveness of business training. When designing business training programs, MFIs should consider various factors to make them useful since the objective of business training is to improve 
the performance of MFIs and owner-managers. Studies (Shaw, 2004) show that MFIs should provide demanddriven training programs to its clients. It is important as there is a lack of demand for business training. Otherwise, it is not practical. Gunathilka's (1997) and Shaw's (2004) studies based in Sri Lanka show that the training given by the Sri Lankan MFIs had failed as they were supply-driven.

The literature on microfinance (Abeysekera, 2016) shows that trainers must have expertise in business knowledge and experience to deliver significant business training programs. The extant literature (Abeysekera, 2016) also shows that the clients prefer internal trainers over external trainers in the context of business training. Moreover, the clients perceive internal trainers as business partners and are more familiar with them. Similarly, De Wildt's (2004) study in Peru also shows that internal trainers are better than external trainers in quality delivery.

The effectiveness of business training could be affected by whether the training is compulsory or voluntary for the owner-managers. The extant literature shows that there are advantages and disadvantages of both types. On the one hand, Sievers and Vandenberg (2007) assert that the clients should attend training provided by MFIs voluntarily based on their need assessments. On the other hand, Ladzani and Vauren (2002) argue that clients must be given compulsory training before microcredit being given to avoid business failures. They say that the clients who have undergone business training would utilize the microcredit wisely and manage the business well. Charging a fee for business training or providing business training free of charge could affect training effectiveness. The literature on microfinance shows that business training should be provided free to clients to show up to training (DPRN, 2009; Sievers and Vandenberg, 2007). However, some studies reveal that even poor clients are willing to pay a small amount as a fee for training and hence, MFIs must charge a fee to sustain the business training (Goldmark, 2006; Abeysekera, 2016).

The literature on microfinance shows that business training should be provided in a location close to the client's operating base to save on transportation cost and time (Halder, 2003). The literature also iterates that clients prefer short term training as opposed to long term training. The time of the day is also essential in conducting business training as clients cannot attend training when they are busy (Abeysekera, 2016). The literature reveals that the clients prefer lunchtime and evenings to attend such training (Walker et al., 2007). Thus, the relationship between the training in small business/microfinance and the performance is dependent on the various factors. For example, the macro-environment could affect business training's effectiveness and, thus, affect the performance. If there is a lack of demand for business training from the clients, then the training's effectiveness will suffer as MFIs and clients cannot achieve desired performance objectives.

Further, the characteristics of trainers and trainees (i.e., expertise) and how they interact in training programs have a bearing on the effectiveness of training. Moreover, it is essential to understand why MFIs are motivated to deliver business training and why clients (trainees) are motivated to receive business training to evaluate business training effectiveness. This study uses the Industrial Marketing Purchasing Group (IMP) interaction model to identify the factors that affect business training effectiveness.

2.4 Industrial Marketing Purchasing Group (IMP) interaction model. This study focuses on the business training given by MFIs to owner-managers of microenterprises. Hence, it is appropriate to use the interorganizational theory, such as the IMP interaction model, to explore business training's effectiveness. The IMP group developed a theoretical model based on empirical data obtained from 800 customer-supplier relationships in 1982 (Hakansson and Snehota, 2000; Easton, 1992, in Axelsson and Easton, eds., 1992; Hakansson, ed., 1982). They found four groups of variables that characterize a relationship (illustrated in Figure 1): the interaction process, the interacting parties, the interaction environment, and the atmosphere (Hakansson, 1982). The first three groups of the model describe different relationships, while the last group (i.e., atmosphere) gives a mediating effect to the interaction process (Hakansson, 1982). 


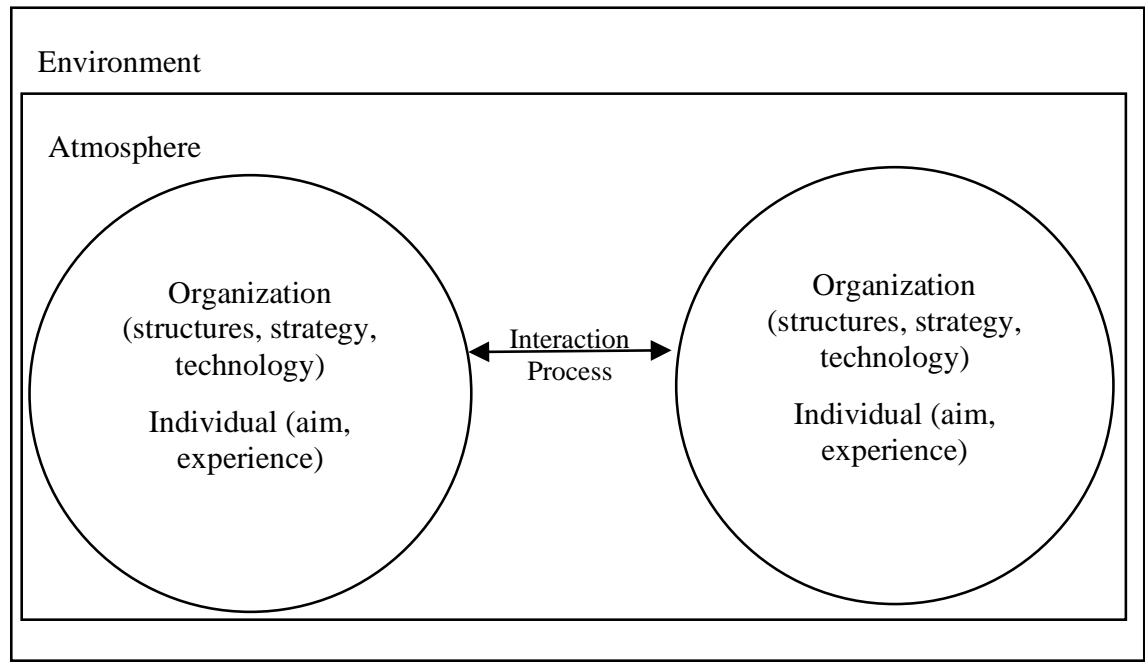

Figure 1. Industrial Marketing Purchasing (IMP) group framework

Source: Compiled by the author

The interaction environment. The environment in which business training takes place would influence training and performance. The general economic climate, level of competition, availability of funds, technical sophistication, and social expectations could be parts of the interaction environment, which could influence the training-performance dyad.

The atmosphere. It is pivotal to examine the atmosphere in which training takes place. The atmosphere is associated with the relationship between the provider and the recipient. The relationship is dependent on the economic benefits and the control of the parties. The economic dimension concerns the benefits of having a relationship, whereas control measures which party controls the other. In essence, the atmosphere looks at motivators of each party to be in a relationship. Therefore, in the present study, MFIs and owner-managers' motivators to engage in training are examined.

The interaction parties. The interaction parties consist of the structures, systems and personalities of the parties involved. The differences between the parties determine the interaction between the parties. In this study, trainers and trainees' characteristics are examined to determine how expertise and the type of trainer (i.e., internal, external) can affect the business training intervention.

The interaction processes. The interaction happens between the parties which could be organizations or individuals. There are four types of exchanges between parties: product or service exchange, finance exchange, information exchange, and social exchange. When these exchanges become repetitive, the parties could reap benefits, such as cost reduction and increased revenues. In this study, the interaction between trainers and trainees is observed to identify how trainers use communication to deliver effective business training programs and how training location and time affect business training effectiveness.

\section{Research Methodology}

Exploring the factors influencing business training effectiveness in the microfinance field is a contemporary phenomenon that needs to be explored in the real-life context. Hence, the case study method was selected for this study as it allows for the identification of rich insights in the phenomena and provides a holistic picture of the phenomena (Yin, 2009). By following Eisenhardt's (1989) suggestion of using four or ten cases to achieve theoretical saturation, six cases (i.e., MFIs) were chosen for the study. The unit of analysis for this study are individuals that represent both the MFIs and the microenterprises. Purposive sampling was used to select cases and individuals for the study. Cases were chosen based on the type of MFI (i.e., government, bank) and the type of lending methodology (i.e., group lending and individual lending). A trainer, a manager, and one owner manager/client of each MFI were chosen for in-depth interviews.

The details of the MFIs and interviewees chosen for the study are given below in Table 1 . 
Table 1. The details of MFIs and interviewees selected for the study

\begin{tabular}{|c|c|c|l|}
\hline MFIs & Type of MFI & \multicolumn{1}{|c|}{$\begin{array}{c}\text { Lending } \\
\text { methodology }\end{array}$} & \multicolumn{1}{|c|}{ Interviewees } \\
\hline MFI-1 & Public company & Group & $\begin{array}{l}\text { Manager (Enterprise services development manager) } \\
\text { Trainer (Diploma in business management) } \\
\text { Owner manager (engages in furniture business) }\end{array}$ \\
\hline MFI-2 & Non-bank & Group & $\begin{array}{l}\text { Manager (Enterprise services manager) } \\
\text { Trainer (Diploma in Business, Master trainer) } \\
\text { Owner manager (engages in coir business) }\end{array}$ \\
\hline MFI-3 & Private bank & Individual & $\begin{array}{l}\text { Manager (Senior manager micro credit and BDS) } \\
\text { Trainer (Advanced Level examination) } \\
\text { Owner manager (Engages in Garments business) }\end{array}$ \\
\hline MFI-4 & Private company & Group & $\begin{array}{l}\text { Manager (General manager) } \\
\text { Trainer (Diploma in Agriculture) } \\
\text { Owner manager (Owns and manages a rice mill) }\end{array}$ \\
\hline MFI-5 & Non-Governmental Organization & Group & $\begin{array}{l}\text { Manager (General Manager) } \\
\text { Trainer (Diploma in business) } \\
\text { Owner manager (owns a grocery) }\end{array}$ \\
\hline MFI-6 & Government & $\begin{array}{l}\text { Manager (BDS manager) } \\
\text { Trainer (Diploma in business) } \\
\text { Owner manager (engages in garments business) }\end{array}$ \\
\hline
\end{tabular}

Source: Compiled by the author

A pilot study was conducted with a trainer, a manager, and an owner manager/client to improve the semistructured questionnaire. Eighteen interviews (3 from each MFI) were conducted by visiting MFI offices and the business premises of owner managers. The length of the interviews fluctuated from 45 to 60 minutes. Both English and Sinhala languages were used to conduct interviews. All the interviews were tape recorded and transcribed. Informed consent was obtained from all the respondents to follow ethical considerations. Analytical techniques such as cross-case syntheses, and pattern matching were used to analyze the data. The reliability of the study was accomplished by following the case study protocol. Construct, internal and external validity were accomplished by using multiple data sources, pattern matching and using multiple cases.

\section{Findings}

The findings are presented based on the research questions.

Research question 1: How does the operating environment affect business training-performance dyad? The findings from the cases show that a lack of funds and lack of demand from the clients affect business training effectiveness. The following quotations show how a lack of funds affects business training.

The manager of MFI-2 expressed: "In the past, we got money from funders. For example, we had three microfinance projects in Kandy, Polpitigama and Monaragala with "Plan Sri Lanka" under which training was provided to the clients. We are not getting funds from funders and donors for business training as we used to get. It is mainly since Sri Lanka has been promoted to a lower middle-income country”.

The manager of MFI-1 expressed: "Central bank has imposed a rule so that certain MFIs cannot accept deposits from the public. It has resulted in the funding of these MFIs and in turn, it has badly affected business training".

The findings also reveal a lack of demand from the clients for business training programs offered.

The manager of MFI-5 said: "When we organize training programs, clients are reluctant to attend. They think that attending the training is a waste of money and time. So sometimes we provide incentives such as meal allowance and transportation for clients to attend. Even when they do attend, I have seen some clients throw away the training materials after the training".

Research question 2: How does the atmosphere affect business training - performance dyad?

The findings reveal that MFIs provide business training due to the donor's request, mission statement, profit orientation, and broad social and economic goals. The following quotation shows how the donor's request influences business training.

The manager of MFI-4 stated: “We need some time to provide BDS to fulfill donor's /funder's requests. They want us to utilize a certain percentage of funds that they provide for BDS. So we have to offer business training to our clients". 
The findings show that MFIs mission statements triggered MFIs to provide business training to clients. Two of the mission statements of the MFIs taken for the study are given below as evidence for MFIs' motivation to provide non-financial services, including business training to clients in addition to microcredit. The mission of MFI-1 states: "ensure the accessibility of the poor to quality microfinance and enterprise development at the lowest possible price". In the mission statement of MFI-5 it prioritized the ability to "offer both financial and non-financial services including social, spiritual, and environmental services for the empowerment of disadvantaged communities".

In these statements, business training is recognized under "enterprise development" and "non-financial services". All the top managers interviewed from the MFIs stated that they provided business training to ownermanagers under BDS having been guided by the mission statement of their respective MFIs. The following is one of the quotations which shows the encouragement and guidance offered by the mission statement.

The manager of MFI-5 stated: "Credit is not enough to develop micro-entrepreneurs. We have to provide Credit plus (BDS) also to our clients. That is in our mission statement. That is why we set aside $30 \%$ of our profits to provide BDS, including business training to our clients".

Their profit or non-profit orientation could also influence the motivation to provide business training by an MFI. Except for MFI-3, all the other MFIs selected for the study were found to be non-profit oriented. Since shareholders of profit-oriented MFIs are concerned about achieving the bottom line, they are reluctant to spend money on business training, which they consider to be a cost. Thus, it is likely that profit-oriented MFIs would not pay or would only spend a little on business training, whereas non-profit oriented MFIs who are more concerned about social objectives would spend more on business training. The findings further reveal that MFIs provide business training to achieve social and economic goals, such as creating new ventures and job opportunities and better loan repayments. The following quotation substantiated MFIs' objective of achieving social and financial goals.

The manager of MFI-2 expressed: "There are many benefits we gain from business training. We can create new ventures and give more job opportunities. Further, we can have better loan repayments since the clients who underwent business training would repay the loans taken".

Motivational Factors of owner-managers in obtaining business training. Findings show that ownermanagers were motivated to obtain business training to fill their knowledge gaps and improve their business performance. All interviewed owner-managers agreed with this statement, and the following is one of the quotations to substantiate this claim.

The owner-manager of MFI-1 stated: "We like to take part in business training because it helps us improve our business knowledge, sales and profits in our businesses". Thus, MFIs would provide business training to clients and clients would obtain business training as both parties have the motivation for business training.

Research question 3: How do interacting parties affect business training-performance dyad?

The findings of the study show that characteristics of trainers and owner-managers/client (i.e., interacting parties) affect the business training-performance dyad. Therein, conclusions relating to trainers are presented first and then those related to the owner-managers are given. The findings depict that the trainers' characteristics chosen for this study vary in terms of trainer's expertise, which includes business knowledge and experience, trainers' being internal/ external and trainers' being full-time/part-time nature. Therein, the table below (Table 2) compares the expertise of internal trainers of MFIs studied.

Table 2. Expertise of internal trainers in MFIs studied in terms of qualifications and experience

\begin{tabular}{|c|l|l|}
\hline MFI & \multicolumn{1}{|c|}{$\begin{array}{c}\text { Educational qualifications, trainings } \\
\text { undertaken, experience }\end{array}$} & \multicolumn{1}{|c|}{ Type of business training provided } \\
\hline MFI-1 & $\begin{array}{l}\text { Degree/Diploma in business management, } \\
\text { undergone many Training of Trainers (TOT) in } \\
\text { Business management, 05 years of experience in } \\
\text { training }\end{array}$ & $\begin{array}{l}\text { Financial literacy, basic business management (record keeping, } \\
\text { idea generation, business plan preparation, marketing, inventory } \\
\text { management, costing, business planning, buying) }\end{array}$ \\
\hline MFI-2 & $\begin{array}{l}\text { Degree/Diploma/Advanced level (A/L) } \\
\text { examination in business, undergone a few TOT in } \\
\text { Business management programs, 20 years of } \\
\text { experience in training }\end{array}$ & $\begin{array}{l}\text { Financial literacy, basic business management (record keeping, } \\
\text { idea generation, business plan preparation, marketing, inventory } \\
\text { management, costing, business planning, buying) }\end{array}$ \\
\hline MFI-3 & $\begin{array}{l}\text { A/L examination and Banking examinations, 10 } \\
\text { years of experience in training }\end{array}$ & Financial literacy, Inventory management, Marketing \\
\hline
\end{tabular}


Table 2 (cont.). Expertise of internal trainers in MFIs studied in terms of qualifications and experience

\begin{tabular}{|c|l|l|}
\hline MFI-4 & $\begin{array}{l}\text { A/L examination and diploma in agriculture, 15 } \\
\text { years of experience in training }\end{array}$ & $\begin{array}{l}\text { Financial literacy, basic business management (record keeping, } \\
\text { business plan preparation) }\end{array}$ \\
\hline MFI-5 & $\begin{array}{l}\text { A/L examination, Diploma in Business } \\
\text { management, TOT in Business management, 05 } \\
\text { years of experience in training }\end{array}$ & $\begin{array}{l}\text { Financial literacy, basic business management (record keeping, } \\
\text { business plan preparation) }\end{array}$ \\
\hline MFI-6 & $\begin{array}{l}\text { Degree/Diploma in Business, 20 years of } \\
\text { experience in training }\end{array}$ & $\begin{array}{l}\text { Financial literacy, basic business management (record keeping, } \\
\text { business plan preparation) }\end{array}$ \\
\hline
\end{tabular}

Source: Compiled by the author

As can be evidenced from the above table, the trainers' expertise varies. From the findings, the trainers of MFIand MFI-2 were able to provide many business training programs due to their higher expertise than the trainers of other MFIs. MFIs use full time/part-time, internal/external trainers to provide business training. The managers and officers could provide training in addition to their primary role and are thus part-time trainers. The findings reveal that full-time trainers were better prepared to provide training since they had more time than part-time trainers. In contrast, part-time trainers had to manage their time with their main job role to provide training. However, many MFIs get part-time trainers' services because they cannot afford to have fulltime trainers despite their efficiency. The following table (Table 3) further explains the nature of the trainer's job (full-time/part-time) and types of training they delivered.

Table 3. Characteristics of trainers representing each MFI and type of training they provided

\begin{tabular}{|c|c|c|c|}
\hline & \multicolumn{2}{|c|}{ Internal trainers } & \multirow{2}{*}{ External trainers } \\
\hline & Full-time & Part-time & \\
\hline MFIs & MFI-2 & $\begin{array}{c}\text { MFI-1, MFI-3, MFI-4, MFI-5, } \\
\text { MFI-6 }\end{array}$ & $\begin{array}{l}\text { MFI-1, MFI-2, MFI-3, MFI-4, } \\
\text { MFI-5, MFI-6 }\end{array}$ \\
\hline $\begin{array}{c}\text { Type of Training } \\
\text { provided }\end{array}$ & $\begin{array}{l}\text { Financial literacy training, } \\
\text { business training, office bearer } \\
\text { training }\end{array}$ & $\begin{array}{l}\text { Financial literacy training, } \\
\text { business training, office bearer } \\
\text { training }\end{array}$ & $\begin{array}{l}\text { Vocational training, business } \\
\text { training }\end{array}$ \\
\hline
\end{tabular}

Source: Compiled by the author

MFIs use both internal and external trainers to provide training. External trainers were used when internal trainers do not possess the competency, and in instances when external trainers provide free business training under the government entrepreneurship development programs. The findings show that MFIs prefer internal trainers over external trainers due to internal trainers' flexibility and follow up on the training provided. The following is one of the excerpts to support this.

The manager of MFI-1 expressed: "We realized that it was difficult to get external trainers due to their schedule. Further, our clients sometimes cannot attend training on the given dates by external trainers. So, we thought of having our own trainers to set the dates based on the clients' convenience and do follow-up training. Further, we can maintain the quality of the training which meets both the client and our requirements".

Furthermore, clients/owner-managers interviewed believe that internal trainers are better than external trainers as they are more familiar with the internal trainers and could contact them and give feedback. The following quotation can substantiate this claim.

The owner-manager of MFI-5 said: "We prefer trainers coming from MFIs rather than outside because we know them personally. They call us to follow up with training and we have a good relationship".

The findings also show that an owner manager's characteristics, such as organizational structure and expertise, could affect the business training-performance dyad. In this light, the study's findings show that all the owner-managers interviewed for the survey manage microenterprises in which there are no separate departments/functions, such as finance and marketing, as in larger organizations. Thus, owner-managers need to have knowledge about all the functions and for which they may need to undertake training. The findings also reveal that owner-managers chosen for the study possessed low expertise in business knowledge; the formal education of selected owner-managers for this study was often low. None of them have obtained a degree and the majority have only learnt up to the 11th grade.

Research question 4: How does the interaction process affect business training-performance dyad?

The findings show that the trainer's expertise, readiness, follow up and feedback, and owner manager's knowledge and willingness affect the interaction between the trainer and the trainee and the trainingperformance dyad. Further, contextual factors such as the location of the training, duration, timing of training 
affect the interaction. The findings reveal that the trainers' expertise is vital for the interaction between the trainers and trainees. Trainers need to have expertise in terms of business knowledge and experiential knowledge. It is evident from the following quotation.

The trainer of MFI 2 stated: "We as trainers need to have both business knowledge and experiential knowledge to deliver business training. Trainees follow us due to our expertise. We gather business knowledge through qualifications such as business degrees and by following Training of trainers (TOT) programs. Further, we acquire experiential knowledge by conducting training programs and managing our businesses".

The low level of owner-manager expertise is key to the interaction, given that such interaction arises out of the gap in the level of knowledge between trainers and owner-managers. The following is a quotation to substantiate this.

The manager of MFI-6 stated: "Our clients often do not have the business knowledge gained through qualifications such as degrees and diplomas. There are some illiterate clients as well. So they need to undergo business training”.

The findings also show that the owner-managers willingness is essential for the interaction. Owner managers attend training due to their willingness. The owner-manager spends money, time and puts in efforts to take part in the training. The importance of desire for training is highlighted in the following excerpt.

The trainer of MFI-5 stated: "Willingness of the client to attend training is very important. They will attend training if they are willing only".

The findings show that trainer readiness in terms of the amount of time available to provide training could affect training effectiveness. The interview data show that the trainer's willingness can be affected by his/her nature of the job (i.e., full time/part-time). The trainers interviewed from all MFIs except MFI-2 mentioned that they were part-time trainers and did not fully engage in training.

The trainer of MFI-5 stated: "My main role is to work as an assistant accountant. But I work as a part-time trainer and deliver training when necessary. Due to my main role's workload sometimes, I cannot provide training".

The trainer of MFI-2 admitted that they had enough time to provide training.

The trainer of MFI-2 stated: "At MFI-2 we have full-time trainers and we provide many training programs as we have time and are committed to training."

The findings show that trainer communication was critical in training and thus in interaction as well. The results further reveal that trainers should use non-technical words, need to know different languages, and should use communication tools to enhance communication. Further, they should use motivational communication. The following quotations substantiate it.

The trainer of MFI-6 stated: "We do not use technical jargon when providing training to microfinance clients. Further, we need to be conversant in languages spoken in Sri Lanka”.

The trainer of MFI-1 expressed: "We use whiteboards, interactive training techniques such as role-plays and group work to interact with the trainees. Further, we use motivational communication to retain the trainees in the class otherwise, they skip the training".

The findings showed that the trainer's follow-up and feedback to attendees (owner-managers) after the training were essential in training.

The trainer of MFI-1 indicated: "We have to send a report to Enterprise Development Manager regarding follow up and feedback on training. For example, when the 'Improve Your Business' training program is over, after one month, we have to visit the client to see whether the client has implemented what was learnt. Doing follow up and feedback by the trainer himself is not practical. Sometimes the trainer trains thousands of clients. Therefore, sometimes EDO does the follow-up and feedback for selected trainees".

Location, duration, fee, voluntary/ compulsory nature and subsidies of training. The findings show that the training location, time, duration, charging a fee, the voluntary/ compulsory nature of training, and subsidies affect the business training-performance dyad. The findings reveal that clients prefer to have a training location close to their operating bases such as temples, schools and community centers. Moreover, they like to have training programs with a shorter duration (e.g., half a day to three days). It was found that some MFIs (e.g., MFI-2) charge a fee for training, whereas others provide training free of charge. Providing training free of 
charge could attract clients to attend training. However, it was found that clients would give more value to business training if MFIs charge even a small fee for training. All the MFIs selected for the study made training, voluntary but the MFIs offering group lending facilities urge the clients to participate in training through group meetings. MFI-5 and MFI-6 provided food and transportation subsidy to clients to attend training, which has helped poor clients. Given below are some quotations to corroborate location, duration, fee, voluntary nature and subsidies.

The trainer of MFI-1 stated: "When conducting training we consider a location close to our trainees. For example, we conduct training in temples and schools. Further, we do not conduct training with longer periods because than trainees cannot attend due to their commitments".

The trainer of MFI-2 expressed: "We charge for training and it is Rs. 1000 per day. Some MFIs do not charge for training. Further, attending training is voluntary for our clients".

The trainer of MFI-6 stated: "We provide food and transportation allowances for our clients to attend training”.

The findings can be summarized in the following table.

Table 4. Summarized findings

\begin{tabular}{|l|l|}
\hline \multicolumn{1}{|c|}{ IMP group of variables } & \multicolumn{1}{|c|}{ Themes } \\
\hline Operating environment & $\begin{array}{l}\text { Lack of funds } \\
\text { Lack of client demand }\end{array}$ \\
\hline Atmosphere & $\begin{array}{l}\text { Motivators for MFIs } \\
\text { Donor's requests, mission statement, profit orientation, achieving social and economic goals } \\
\text { Motivators for Clients } \\
\text { Filling their knowledge gaps and improving business performance }\end{array}$ \\
\hline Interacting parties & $\begin{array}{l}\text { Trainer's characteristics such as expertise, full time/part time, or whether internal or external } \\
\text { to MFIs } \\
\text { Client/owner manager characteristics such as organizational structure and expertise }\end{array}$ \\
\hline Interacting process & $\begin{array}{l}\text { Trainer expertise, communication, readiness, follow up and feedback, client expertise and } \\
\text { willingness } \\
\text { Location, duration, fee, voluntary/ compulsory nature and subsidies of training }\end{array}$ \\
\hline
\end{tabular}

Source: Compiled by the author

\section{Discussion, Conclusions and Implications}

This study uses the IMP framework to explore the factors affecting the business training-performance dyad. The study results show that the operating environment affects business training, which could influence business performance. Lack of donor money, competition and low demand for business training were identified as factors under the operating environment that could affect the dyad. The findings also show that the atmosphere affects the dyad. MFIs engage in training due to donors' requests, mission statement, profit orientation of the institution, and the inclination of achieving social and economic goals, such as through the creation of new ventures and job opportunities. Owner managers engage in training because they would like to have better business knowledge, skills, and sales and profits. Trainers and trainees (i.e., owner-managers) are the main interacting parties in the business training intervention. It was found that trainer characteristics, such as trainer expertise, trainer being internal or external, and trainer being full-time or part-time and ownermanager characteristics, such as the organization's expertise and structure, affect the effectiveness of training.

Moreover, the findings reveal a few factors that improve the interaction process between the trainers and the owner-managers. They are the expertise of trainers and owner-managers, trainer's readiness, communication, follow-up and feedback, and the owner manager's willingness. Furthermore, the study revealed that the location and duration of the training, charging a fee or not, training being voluntary or compulsory, and provision of subsidies could influence the interaction between the trainer and the owner-manager. The findings are guided by Patton et al. 's (2000) conceptual paper on the relationship between the training and small business performance where the authors suggested the use of the IMP framework. The microfinance literature (Gibb, 1997; Copestake et al., 2001; Henry, 2006; Karlan and Valdivia, 2006) has not made a comprehensive study to identify the factors affecting the business training-performance dyad. However, it has been identified that some factors such as low demand, lack of donor funds, the expertise of trainers, and trainers being internal could influence the training-performance dyad.

Further, the existing literature (Karlan and Valdivia, 2006) points out that business training provides benefits, such as better loan repayments to MFIs and better business knowledge and practice to owner-managers. These 
factors in the literature are consistent with the findings of the study. In addition to these factors, this study has identified many new factors that affect the dyad, such as trainer readiness, training location and duration using the IMP framework. Thus, this study is a comprehensive and novel study made to identify factors that influence business training and performance dyad.

The study results could help practitioners and policymakers improve the effectiveness of business training, leading to enhanced performance. In effect, they could look at the operating environment, atmosphere, interacting parties, and the interacting processes to improve the business training intervention. Further, this study contributes to the microfinance and small business knowledge domain. Future research can be done to examine other training interventions such as vocational training using the IMP framework.

6. Funding. There is no funding for this research.

\section{References}

1. Abeysekera, R. (2016). Enhancing entrepreneurship in Sri Lanka: the provision of business development services (BDS) by microfinance institutions to support the self-sufficiency of microenterprises (Doctoral dissertation, Bournemouth University). Available at: http://eprints.bournemouth.ac.uk/24721/.

2. ADB (1997). Microenterprise development: Not by credit alone. Manila: Asian Development Bank. Available at: https://www.findevgateway.org/library/microentreprise-development-not-credit-alone.

3. Copestake, J., Bhalotra, S., and Johnson, S. (2001). Assessing the impact of microcredit: A Zambian case study. Journal of Development Studies, 37(4), 81-100. https://doi.org/10.1080/00220380412331322051.

4. DPRN (2009). Stimulating business development: another role for micro finance? Seminar 1, MFIs in developing countries, DPRN Phase II - Report no. 2. Amsterdam: Development Policy Review Network. Available at: http://www.bibalex.org/Search4Dev/files/299084/128389.pdf.

5. De Wildt, M. (2004). Linking business development services to financial services: The case of Financiera Solucio'n. Geneva: ILO. Available at: http://www.bdsknowledge.org/dyn/bds/docs/422/MdRdW-Peru.pdf. Accessed 10 September 2019.

6. Easton, G. (1992). Industrial Networks: A review. In: Axelsson, B. and Easton, G., eds. 1992. Industrial Networks: A new view of reality. London: Routledge, 3-27. DOI/Available at: https://doi.org/10.4324/9781315629629.

7. Eisenhardt, K. M. (1989). Building theories from case-study research. Academy of management review, 14(4), 532-550. https://doi.org/10.5465/amr.1989.4308385.

8. Gunatilaka, R. (1997). Credit-based participatory micro enterprise development, poverty alleviation strategies in Sri Lanka: What have we learned? Sri Lanka: Institute of Policy Studies. Available at: https://www.ips.lk/credit-based-participatory-poverty-alleviation-strategies-in-sri-lanka-what-have-welearned/.

9. Gibb, A.A. (1997). Small firms' training and competitiveness. Building upon the small business as a learning organization. International small business journal, 15(3), 13-29. https://doi.org/10.1177\%2F0266242697153001.

10.Goldmark, L. (2006). Beyond finance: microfinance and business development services. In: Berger, M., Goldmark, L. and Miller-Sanabria, T., Eds. An inside view of Latin American microfinance. Washington, DC: Inter-American Development Bank, 1-27. Available at: https://www.findevgateway.org/sites/default/files/publications/files/mfg-en-paper-an-inside-view-oflatin-american-microfinance-2006.pdf.

11.GTZ ProMiS (2010). Micro Finance Industry Report. Sri Lanka: GTZ ProMiS and The Banking with the Poor Network. Available at: https://www.findevgateway.org/sites/default/files/mfg-en-papermicrofinance-industry-report-sri-lanka-2010.pdf.

12.Halder, S.R. (2003). BRAC's Business Development Services-do they pay? Small enterprise development, 14(2), 26-35.

Available at: https://pdfs.semanticscholar.org/35f2/61b1cbfd070f0410dadb2e0707a7c0c6f3f2.pdf.

13. Hakansson, H., and Snehota, I. (2000). The IMP perspective, assets and liabilities of relationships. In: Sheth, J. and Parvatiyar, A., eds. Handbook of relationship marketing. Thousand Oaks, Ca: Sage. Available at: https://www.amazon.com/Handbook-Relationship-Marketing-Atul-Parvatiyar/dp/0761918108.

14.Hakansson, H. (1982). International Marketing and Purchasing of Industrial Goods. New York: John Wiley \& Sons. Available at: https://www.impgroup.org/uploads/books/InternationalMarketing.pdf.

15.Henry, S. (2006). Good practice in business development services: How do we enhance entrepreneurial skills in MFI clients? [Online]. Toronto: Alterna Savings. Available at: http://www.ruralfinanceandinvestment.org/node/59. 
16.Karlan, D., and Valdivia, M. (2006). Teaching Entrepreneurship: Impact of Business Training on Micro Finance Clients and Institutions. Economic Growth Centre Discussion Paper, 941, 510-527. Yale University: Economic Growth Centre. https://doi.org/10.1162/REST a 00074.

17.Khavul, S. (2010). Microfinance: Creating Opportunities for the Poor? Academy of management perspectives, 24(3), 58-72. https://doi.org/10.5465/amp.24.3.58.

18.Ladzani, W.M., and van Vuuren, J.J. (2002). Entrepreneurship Training for Emerging SMEs in South Africa. Journal of small business management, 40(2), 154-161. https://doi.org/10.1111/1540-627X.00047.

19.NEDA (2013). Micro enterprise policy paper [Online]. Sri Lanka: National Enterprise Development Authority. Available at: http://www.neda.gov.lk/web/index.php?lang=en.

20.Patton, D., Marlow, S., \& Hannon, P. (2000). The relationship between training and small firm performance; research frameworks and lost quests. International small business journal, 19(1), 11-27. https://doi.org/10.1177\%2F0266242600191001.

21.Shaw, J. (2004). Microenterprise occupation and poverty reduction in microfinance programs: evidence from Sri Lanka. World development, 32(7), 1247-1264. https://doi.org/10.1016/j.worlddev.2004.01.009.

22.Sievers, M., and Vandenberg, P. (2007). Synergies through linkages: who benefits from linking microfinance and business development services? World development, 35(8), 1341-1358. https://doi.org/10.1016/j.worlddev.2007.04.002.

23.Tilakaratne, G., Wickramsinghe, U., and Thusitha, K. (2005). Micro finance in Sri Lanka: a household level analysis of outreach and impact on poverty. Sri Lanka: Institute of Policy Studies of Sri Lanka. Available at: http://www.pep-net.org/sites/pep-net.org/files/typo3doc/pdf/files_events/4th_colombo/Ganga.pdf.

24.Tilakaratne, G., Galappattige, A., and Perera R. (2009). Promoting empowerment through microfinance in Sri Lanka, economic and political empowerment of the poor - Sri Lanka. Sri Lanka: Centre for policy dialogue, South Asia Centre for policy studies. Available at: https://www.ips.lk/economic-and-politicalempowerment-of-the-poor-promoting-empowerment-through-microfinance-programmes/.

25.Walker, E., Redmond, J., Webster, B., and Le Clus, M. (2007). Small business owners: too busy to train? Journal of small business and enterprise development, 14(2), 294-306. https://doi.org/10.1108/14626000710746718.

26. Yin, R. K. (2009). Case-study research: Design and methods 4th edition ed. London: Sage. Available at: https://books.google.lk/books/about/Case_Study_Research.html?id=FzawIAdilHkC\&redir_esc=y. 